HAROLD E. SEELY HONOURED

Harold E. Seely, B.Sc.F., head of the Forest Inventories Section, Forestry Branch, Department of Resources and Development, is the winner of the 1951 Gold Medal of the Professional Institute of the Public Service of Canada. The award was made "for his original scientific work and his application of this scientific work to the field of forestry", and the presentation of the medal was made recently at the Annual Luncheon in the Chateau Laurier.

A gold medal is presented annually by the Professional Institute to the Canadian public servant whose contributions in pure or applied science or to national or world well-being are regarded by a panel of prominent judges as being of outstanding importance. Judges for the 1951 award were Dr. G. Edward Hall, President of the University of Western Ontario; Dr. W. A.

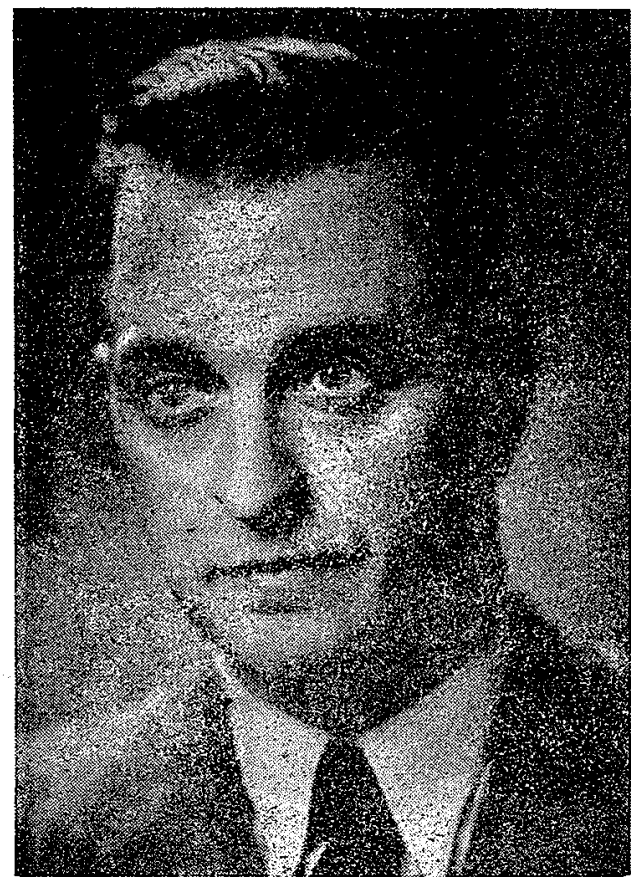

Mackintosh, Vice-Principal of Queen's University, and Dr. Paul E. Gagnon, Head of the Graduating School, Laval University.

Mr. Seely's nomination for the award was based on his accomplishments as a pioneer in the application of air photography to forestry which it was considered constituted a major contribution to the proper investigation and wise management of Canada's forest resources. The judges referred to Mr. Seely's achievements as being of "great importance in the total national economy". His methods and devices had been adopted by others not only in this country but in other countries which in itself was tangible proof of the value to the general public service. Mr. Seely's work was original in concept as he developed new equipment and worked out new techniques in 
order to prove not only his scientific thesis but to make his findings applicable in a practical sense, the judges' report states.

Harold E. Seely is a native of Saint John, New Brunswick, and was graduated in forestry from the University of New Brunswick in 1919. Except for three years in the Army during World War II and brief periods of employment with other organizations, Mr. Seely's professional career has been in the federal Forestry Branch.

His early activitiees included ten years of field work, much of which was in Western Canada where he engaged in forest administration and forest surveys. His experience with air photographs began during field work from 1927-1929 following which he was appointed to full-time duty on air photographs with headquarters in the Forestry Branch, Ottawa. He had gained sufficient field experience to appreciate some of the possibilities of air photographs in relation to forest surveys and had acquired basic qualifications which have assisted in the gradual building up of the present Forest Air Survey Unit, which carries on investigations of new methods in the application of air photographs and takes care of Forestry Branch requirements in forest mapping.

Following overseas service with the Royal Canadian Engineers, he returned to Canada in 1943 and became Officer Commanding an army survey wing in Halifax, Nova Scotia, where men were trained for overseas service in photogrammetry and surveying.

The technique which Mr. Seely has originated and developed in the use of air photographs for forestry purposes has placed the Federal Forestry Branch in the forefront in this new science. On special request, he prepared and delivered the main paper on air photography and its application to forestry at the United Nations Conference on the Conservation and Utilization of Resources at Lake Success in August, 1949.

In 1950, he was elected President of the Canadian Institute of Surveying and Photogrammetry. For some years he has held the office of Chairman of the Standing Committee on Surveys, Canadian Institute of Forestry.

\section{SURRENDER OF CHARTER C.S.F.E.}

The surrender of charter of the Canadian Society of Forest Engineers, the last official act in the dissolution of that organization, was completed in March, 1951. The process involved the transfer of all assets and liabilities to the Canadian Institute of Forestry.

The complicated legal processes involved in this dissolution of the Society were very ably executed by Ross Smith. The Provincial Secretary stated at the time at which the material was presented that every detail had been completed in a very thorough manner.

Ross Smith is a graduate of the Faculty of Forestry, University of Toronto, Class of '49 and is now completing his second year at Osgoode Hall Law School.

Ross's efforts in having so expertly completed this phase of the development of the Institute are greatly appreciated by the Executive and the Board of Directors since outside legal advice of this type is very expensive and no amount of money could have purchased the personal interest which Ross gave to the project. 